\title{
Improving performance of soil covers over waste rock dump tops in dry climates
}

\author{
D.J. Williams School of Civil Engineering, The University of Queensland, Australia
}

\begin{abstract}
Soil covers over mine waste rock dump tops in dry climates are intended to limit the ingress of oxygen and/or to limit the net percolation of rainfall infiltration into the underling potentially reactive waste rock excavated, in particular, on open pit mining. The climate in which the mine is located plays a key role. The aim of limiting the ingress of oxygen into the dump is to minimise the oxidation of any sulphidic waste rock, which is often found on mining an ore body beneath the groundwater table. The aim of limiting the net percolation of rainfall infiltration into an oxidising waste rock dump is to limit the transport of the oxidation products to the environment. In the absence of a water cover, limiting the ingress of oxygen into a dump is best achieved by using a near-saturated soil cover, while limiting net percolation is potentially achieved by applying a rainfall-shedding soil cover, or by applying a store-and-release soil cover.

In practice, there are many impediments to achieving good performance from a soil cover over a waste rock dump. It takes a number of years to construct a waste rock dump as open pit mining proceeds. The waste rock will emerge from the pit in a relatively dry state, and it will readily become, and will remain during construction of the dump, well oxygenated. Hence, there is ample opportunity for sulphidic waste rock in the dump to oxidise during the construction of the dump, so that limiting further oxygen ingress may be of limited value. During construction, a dump is also open to rainfall infiltration, allowing the wetting-up of the dump and the ultimate transport of any oxidation products that form. When the dump is eventually covered, the best that can be achieved is limiting further oxygen ingress and/or limiting the transport of oxidation products. However, this assumes that an effective cover can be constructed. This is made difficult by the ongoing settlement of the dump, by the potential absence of suitable cover materials, by the use of large-scale mine site equipment to construct the cover, by insufficient attention paid to cover design, construction and maintenance, and by climatic variability. The relatively poor performance of dry-climate soil covers over waste rock dumps is compared with the performance of dry-climate soil covers over landfills, which typically display good performance.
\end{abstract}

\section{Introduction}

Worldwide literature and other experience supports the use of store-and-release covers on the tops of waste rock dumps in dry climates, in which the average annual potential evaporation is more than two to three times the average annual rainfall. Most of the available experience in the use of store-and-release covers emanates from Australia and the drier parts of the USA. The concept was first developed (Williams et al., 1997) for Kidston Gold Mines, in north Queensland, Australia, which has a climate dominated by a short wet season and long dry season, potential evaporation many times the amount of rainfall, and few materials well suited for cover construction, like many dry locations. The key elements of a store-andrelease cover are a low hydraulic conductivity layer at its base, a hummocky surface on the thick overlying rocky soil mulch layer, and the appropriate selection of vegetation species to cycle the water stored in the rocky soil mulch layer without a net wetting up or drying out annually.

All soil cover systems are best suited to the relatively flat tops of waste rock dumps. Covers are difficult to construct on steeper slopes. The best treatment of waste rock dump slopes may be to provide a wide encapsulation of benign fresh waste rock, with no reactive waste rock located beneath the slope where it would be intercepted by rainfall infiltration. 


\section{Soil cover design methodology and principles}

The evolution of the soil cover design methodology and principles applied to mine waste rock can be traced through Yanful and Lin (1998), O'Kane and Wels (2003), Rykaart et al. (2006), and the Global Acid Rock Drainage Guide (GARD Guide, 2009), all of which have a North American, or even Canadian, focus. Each of these publications presented similar leading-practice processes for soil cover system design; those described by Rykaart et al. (2006) and the GARD Guide (2009) are presented in the following sections.

\subsection{Flow chart for soil cover system design}

Rykaart et al. (2006) presented a refined 12-step procedure, which is reproduced in Figure 1 . The authors made the point, based on 200 soil cover case studies worldwide, that few mines documented the reason for constructing their soil cover, and very few case studies rigorously followed the full procedure reproduced in Figure 1. Kidston Gold Mines in north Queensland, Australia (Williams et al., 1997, 2006), Barrick Goldstrike Mines in central Nevada, USA (Zhan et al., 2006), Les Terrains Aurifères in Québec, Canada (Ricard et al., 1997), Whistle Mine (Ayres et al., 2002) and Wismut (Diehl, 2011) are among the rare examples. Rykaart et al. (2006) noted an apparent disconnect between mine closure objectives and the selection of mitigation measures (such as soil covers) to address these objectives. As a result, the function required of the soil cover tends to be lost.

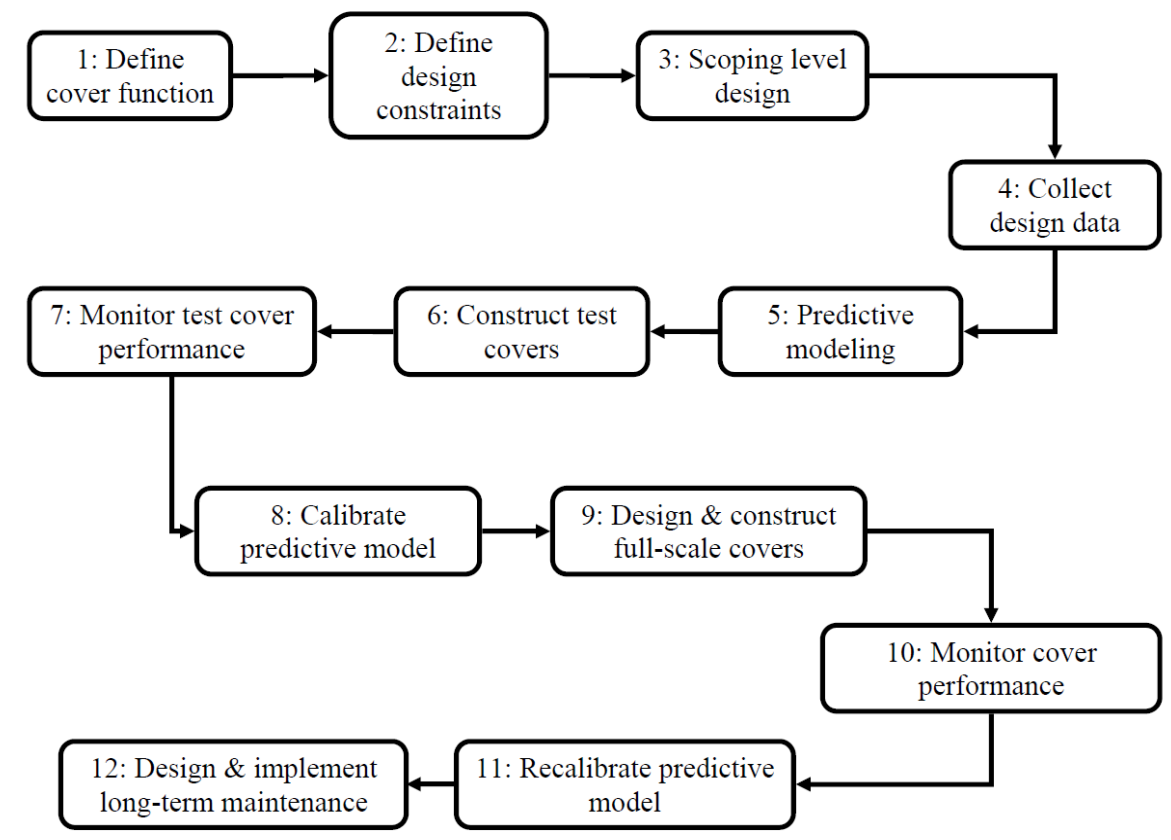

Figure 1 Soil cover design procedure (after Rykaart et al., 2006)

Rykaart et al. (2006) identified the key mine closure objectives in relation to reactive waste rock of minimising human and animal health and safety risks, minimising environmental impacts, and maximising future land use post-mining. Possible soil cover functions for reactive waste rock should include promoting geotechnical stability, stabilising waste (i.e., against dust and erosion), minimising oxidation, minimising seepage to the environment, and promoting vegetation.

Rykaart et al. (2006) highlighted that there are essentially no standard design procedures or designs for soil covers constructed over reactive waste rock. This is in stark contrast to the minimum standards typically enforced by regulation for soil covers over hazardous, industrial and municipal landfills. However, this prescriptive approach for landfill soil covers is being challenged in the USA, with the increasing acceptance of 'alternative' ('evapotranspiration' (ET) or 'store and release') soil covers to the US Environmental Protection Agency (EPA)-prescribed membrane composite 'barrier-type' soil covers (USEPA, 2011), which 
have been shown to perform at least as well as, if not better than, membrane composite covers and which are generally much less expensive.

Rykaart et al. (2006) also discussed soil cover design life, design and construction documentation, construction methods and quality assurance/quality control (QA/QC) and soil cover performance monitoring. The design life nominated for soil covers over reactive waste rock ranges from 100 through 1,000 years to perpetuity, but this is at odds with the expectation that they would be maintenance-free after perhaps 10-20 years and the typical design life for a comparable road pavement of about 20 years. Design and construction documentation, including specifications and as-built plans, is typically limited. The construction of soil covers is all too often carried out solely using large-scale mining equipment, and QA/QC is very limited, unlike the case for civil engineering construction that employs appropriately sized equipment and exercises tight $\mathrm{QA} / \mathrm{QC}$. Soil cover performance monitoring typically includes the direct measurement of seepage rates and quality, where seepage emerges from low points around the toe of the dump, and the use of lysimeters beneath the soil cover (which must be large-scale and properly designed and constructed to provide reliable results), augmented by a local weather station and strings of moisture and suction sensors within the soil cover.

\subsection{GARD Guide recommendations for soil cover design}

The GARD Guide (2009) highlights the need to control the sulphide oxidation rate during mining and processing and reduce oxygen ingress into stored waste rock and/or to reduce the flow of water through oxidising reactive waste rock to limit the transport of oxidation products to the environment. Account must be taken of the delay in the appearance of acid rock drainage (ARD), due to 'delays from chemical processes', particularly those 'related to the hydraulics of waste rock dumps'.

The GARD Guide (2009) highlights the ARD controlling factors, being the climate and physical environment of the mine, the nature of the waste rock, its disposal and storage, the potential for segregation, and the encapsulation and layering of waste rock. Under 'engineered barriers', the GARD Guide describes 'dry' (or soil) covers over reactive waste rock, with the objective of minimising oxygen ingress and/or net percolation, and it adapted the flow chart for the dry (or soil) cover design process of O'Kane and Wels (2003). This recognises the importance of climate, waste rock reactivity and texture, dump geometry, engineering parameters, the hydrological setting of the dump, long-term erosion, desiccation cracking, animal and root penetration, human intervention, degradation and the evolution of the soil cover system.

A chart of appropriate soil cover types as a function of climate is reproduced in Figure 2 (from the GARD Guide, 2009, modified by Wickland et al., 2006). The GARD Guide defines a number of dry (or soil) cover types. Store-and-release covers are defined herein (after Williams et al., 1997) as a soil cover system that is constructed to reduce net percolation by storing rainfall infiltration during higher rainfall periods (the wet season) and releasing stored rainfall infiltration via evapotranspiration during drier periods (the dry season). The GARD Guide states that store-and-release covers perform best in wet/dry climates with high potential evaporation greater than two to three times rainfall.

The GARD Guide makes a distinction between store-and-release covers and 'enhanced' store-and-release covers, which include a compacted, low hydraulic conductivity layer at the base of the cover (possibly compacted waste rock) to 'hold up' infiltrated rainfall. There is no need to make this distinction, since a low hydraulic layer at the base of a store-and-release cover is essential to avoid infiltrated rainfall draining to the underlying waste rock, as highlighted by Williams et al. (1997 and 2006). Canadian experience with store-and-release covers generally is based on the use of the widely available, well-graded, glacial till, containing a silty clay matrix, as the cover material. Such material may be used as a monolithic store and release cover, since it will naturally compact and achieve a low hydraulic conductivity towards its base, fulfilling this requirement.

The thick storage layer overlying the low hydraulic conductivity base layer should be placed loose to maximise water storage and to facilitate vegetation root growth. Williams et al. $(1997,2006)$ refer to this as the 'loose rocky soil mulch layer', and in Australia this often consists of benign, weathered waste rock due 
to the general shortage of other materials. The thickness of this layer should be sufficient to provide adequate storage capacity for the expected rainfall infiltration, without being too thick for vegetation roots to extract moisture through transpiration. A thickness of rocky soil mulch of about $2 \mathrm{~m}$ is typically optimal, providing storage for up to about $500 \mathrm{~mm}$ of rainfall infiltration, which evapotranspiration is generally capable of removing. The selection of appropriate species (trees, shrubs and grasses) is then essential to ensure the establishment of a sustainable vegetation cover with the required transpiration potential.

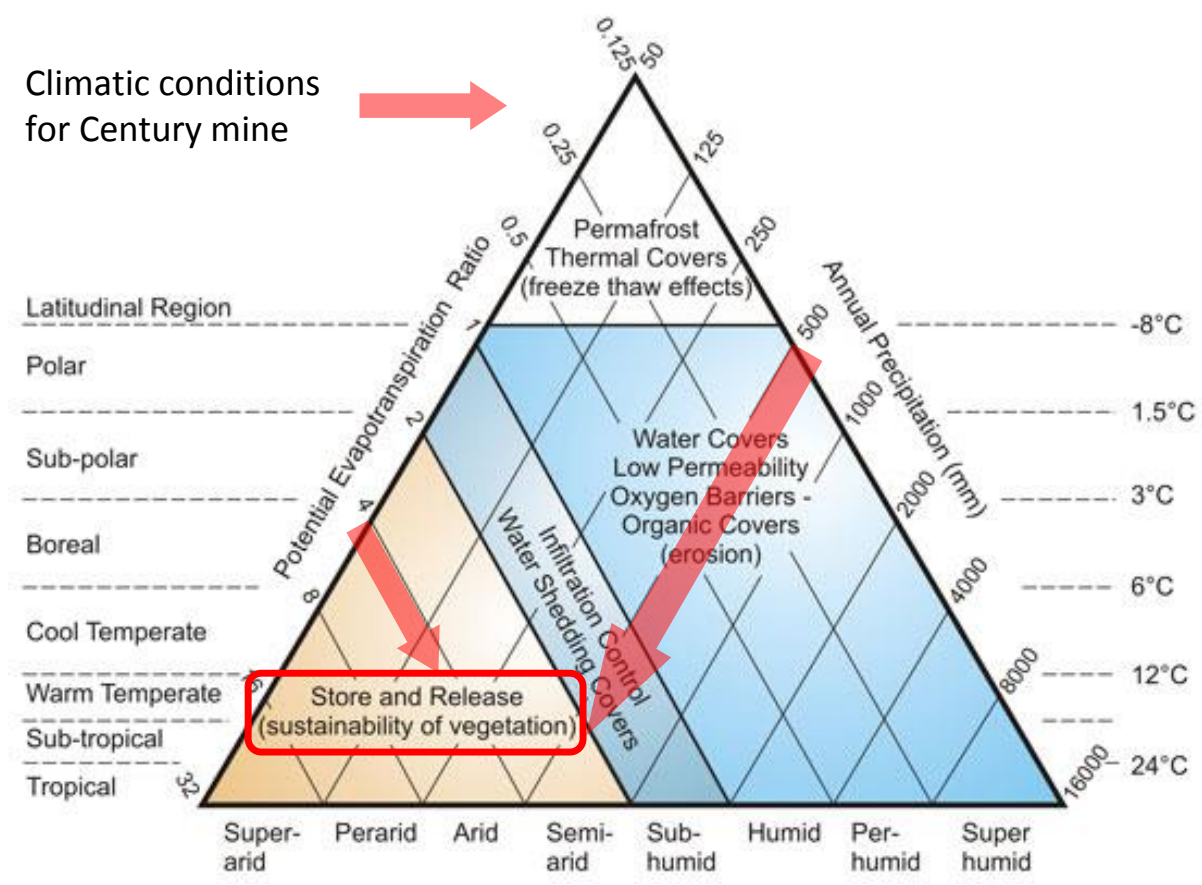

Figure 2 Cover and climate types (from GARD, 2009)

The processes affecting the long-term performance of a soil cover include physical, chemical and biological processes (GARD Guide, 2009, after INAP, 2003). Under Australia's typically dry climate, the main physical processes are erosion, wetting and drying cycles, settlement, extreme climatic events and bushfires. The corresponding main chemical processes are dispersion and erosion, plus dissolution and precipitation, and the corresponding main biological processes are root penetration and burrowing animals or ants. The GARD Guide reported that reviews of 10-15 years of soil cover performance data indicate that soil covers may limit, but not stop, sulphide oxidation and net percolation, but that the reduction in ARD and metal leaching may be sufficient to meet design objectives and at a minimum can reduce mine water treatment requirements.

Soil cover designs applied to mine wastes include (GARD Guide, 2009, after MEND, 2001) monolithic soil covers, inclusion of a capillary break between the soil cover and the waste rock, store-and-release covers and double-capillary break covers. The most common soil cover function types are barrier or rainfallshedding covers and store-and-release covers, although all soil cover systems incorporate some degree of store-and-release functionality. The incorporation of geosynthetics in soil covers over waste rock dumps is not common, in contrast to their extensive use in landfill soil covers.

According to the GARD Guide, the main aims of soil cover performance monitoring are to obtain a water balance for the site, to obtain field performance data to calibrate a numerical model, to develop confidence in the performance of the soil cover system and to develop an understanding of the key site characteristics and processes that control soil cover performance. Monitoring is also important as an indicator of when remedial measures may be needed to repair defects or features that may detrimentally affect performance, such as cracking, erosion, disturbance by tree roots, and burrowing by animals or insects. 
The GARD Guide indicated that waste rock dump soil cover costs can range from about US\$25,000 to US\$100,000/ha, heavily dependent on proximity to borrow sources for soil cover materials. Complex multilayer soil covers and the inclusion of geotextiles can easily double the upper end of this range.

Williams et al. $(1997,2006)$ pointed out that store-and-release covers with a hummocky surface, constructed on the relatively flat top surfaces of waste rock dumps, can harvest all incident rainfall, eliminating surface runoff and the potential for erosion. Barrier covers are rainfall-shedding by design and hence are prone to erosion and desiccation, and they may not sustain vegetation during long dry periods. As a result, barrier covers are far more prone to failure than store-and-release covers, particularly in a seasonally dry climate.

Wilson et al. (2003) stated that Kidston's instrumented store-and-release cover (Williams et al., 2003) and a number of equivalent ET instrumented trial covers constructed under the Alternate Covers Assessment Program (ACAP) for landfills in the USA (Benson, 2002), all in dry climates, generated net percolation of typically less than $1 \%$ of average annual rainfall. The ACAP ET covers performed at least as well as the USEPA-prescribed membrane composite covers in similar climates. Membrane composite landfill covers could cost US\$ 400,000/ha. ACAP's instrumented compacted clay (barrier) covers performed much worse than expected, generating net percolation of up to $50 \%$ of average annual rainfall in humid climates.

The Australian Department of Industry Tourism and Resources (DITR) Leading Practice Handbook on Managing Acid and Metalliferous Drainage states that the minimisation of ARD in a dry climate may require the use of store-and-release covers to reduce net percolation (DITR, 2007). The DITR Leading Practice Handbook on Mine Rehabilitation states that the most effective and sustainable soil cover system for waste rock dumps in a seasonal, dry climate is a store-and-release cover, which mimics natural stream beds (DITR, 2006). It also provides considerable detail on the key elements required to ensure the effectiveness of a store-and-release cover. This is reiterated in the DITR Leading Practice Handbook on Mine Closure and Completion (DITR, 2009).

\section{Development of soil cover system for MMG Century mine dump tops}

The leading practice processes outlined in section 2 were applied, with adaptation for local site conditions, to the development of a soil cover system for the waste rock dump tops in the MMG Century mine in north Queensland. Details of selected elements of the process are discussed in the following sections.

\subsection{Climate}

The Century mine is located in a dry climatic region, with a median annual rainfall of about $500 \mathrm{~mm}$, an average annual rainfall of about $700 \mathrm{~mm}$ and average annual potential evaporation of 2,800 $\mathrm{mm}$ (five and four times the median and average annual rainfall totals, respectively). Rainfall is predominantly during the four months from December to March, and the average number of days of rain/year is 58 , or only $16 \%$ of the year. The minimum and maximum recorded annual rainfall totals are $300 \mathrm{~mm}$ and $1,300 \mathrm{~mm}$, respectively, with up to $650 \mathrm{~mm}$ recorded in a single month (January). The climatic conditions at Century mine indicate a store-and-release cover for the tops of the waste rock dumps, as confirmed by Figure 2 .

\subsection{Waste rock types}

Waste rock characterisation carried out for Century mine by EGi (1997) identified three basic waste rock types, of which the two dominant types were non-acid-generating limestone overlying potentially acidgenerating shale.

\subsection{Available soil cover construction materials and their uses}

The available materials at the Century mine site that have potential for use as soil cover materials are limited to relatively poor silty topsoils and weathered and fresh limestone waste rock. There is an absence 
of clays that could potentially be used to construct compacted sealing layers and an absence of gravels that could potentially be used as capillary break or drainage layers, if these were warranted.

\subsubsection{Achieving a sealing layer}

In the absence of clays, various alternatives were investigated to serve as a compacted sealing layer at the base of the store-and-release cover. The first alternative investigated involved employing an impact roller to further break down and compact dozed waste rock on the top surface of the waste rock dump (see Figures $3(a)$ and $3(b))$. The impact roller has a mass of $12 t$, exerting a static stress at the surface of about $60 \mathrm{kPa}$ over a bearing area of about $1.5 \mathrm{~m}^{2}$ and a dynamic stress at the surface on impact of about $180 \mathrm{kPa}$. The applied stress drops off exponentially with depth. The impact roller was applied to both limestone and shale waste rock. The limestone waste rock broke down readily to a powder under impact rolling (see Figure 3 (c)). However, the degree of compaction achieved was poor, and the resulting saturated hydraulic conductivity remained high. The shale waste rock particles reduced in size on impact rolling without achieving compaction, and the resulting saturated hydraulic conductivity also remained high (see Figure 3 (d)). It appears that much of the impact energy was absorbed in breaking down the rock, rather than in compacting it. The addition of moisture may possibly have been beneficial.

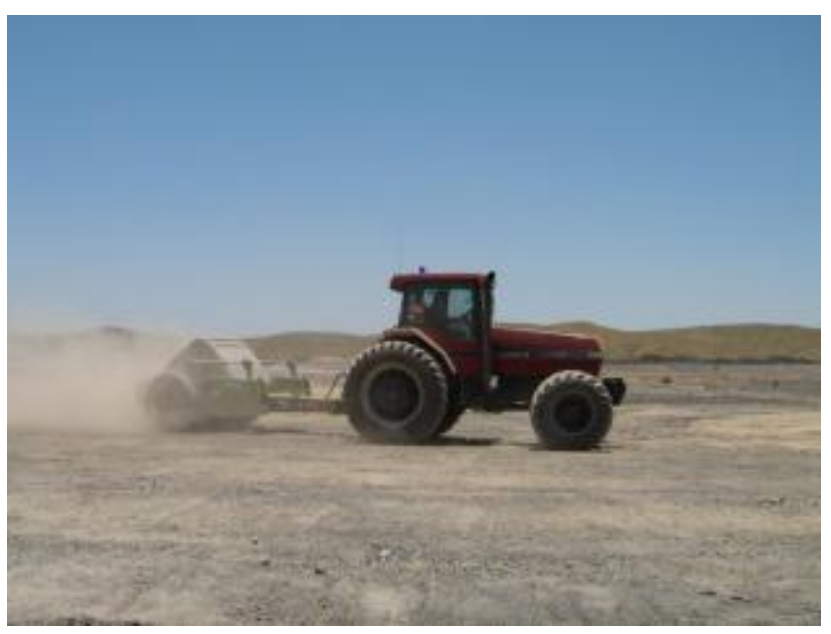

(a)

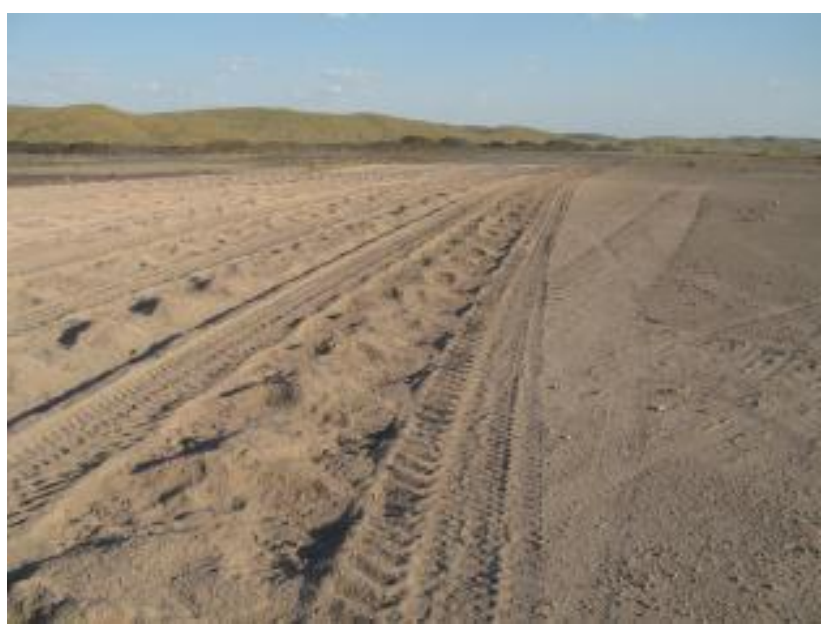

(c)

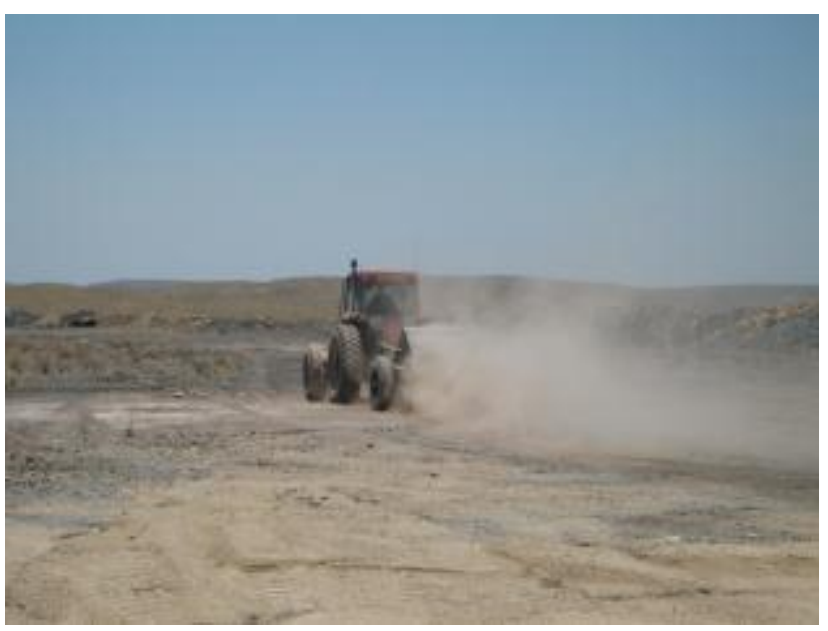

(b)

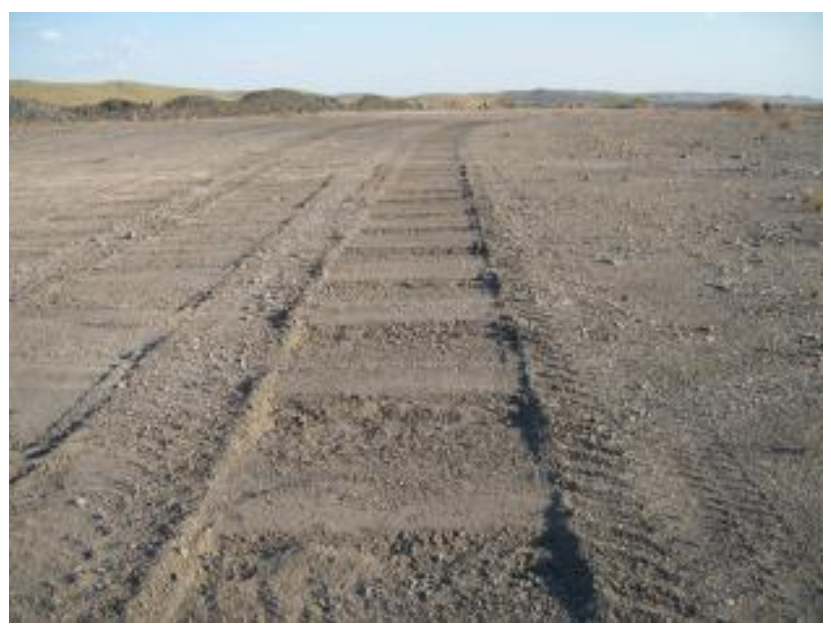

(d)

\section{Figure 3 Impact rolling (a) and (b); and its effect on limestone waste rock (c); and shale waste rock $(d)$}

The second alternative investigated involved mixing topsoil into dozed waste rock on the top surface of the waste rock dump, and then compacting the mixture. While the mixture was more well-graded than the 
waste rock alone, the absence of clay fines in the topsoil inhibited compaction of the mixture and limited the reduction in the saturated hydraulic conductivity. The third alternative investigated, which was ultimately adopted, involved heavily trafficking and watering the dozed waste rock on the entire top surface of the dump using loaded haul trucks, since observation of the main haul roads on the top of dumps showed that extensive trafficking (up to 500 passes by loaded haul trucks/day) and watering for dust suppression was very effective in forming a hardpan surface (see Figures 4 and 5 for limestone and shale waste rock, respectively). Century mine uses Komatsu $830 \mathrm{E}$ Electric haul trucks, with a gross mass when loaded of up to $386 \mathrm{t}$, applying a bearing pressure of over $600 \mathrm{kPa} /$ wheel (to six wheels, each with a bearing surface of about $1 \mathrm{~m}^{2}$ ) -10 times the static bearing pressure of the impact roller and over 3 times its dynamic bearing pressure.

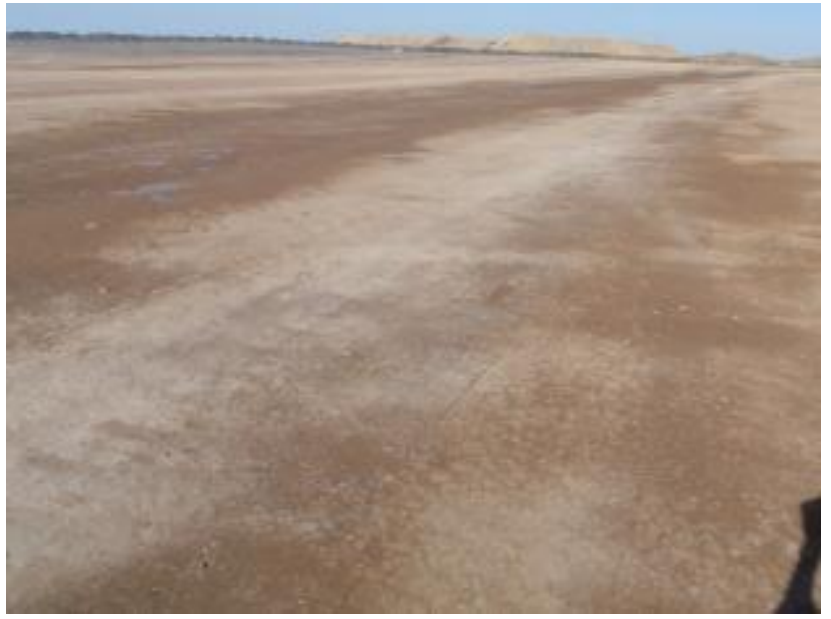

(a)

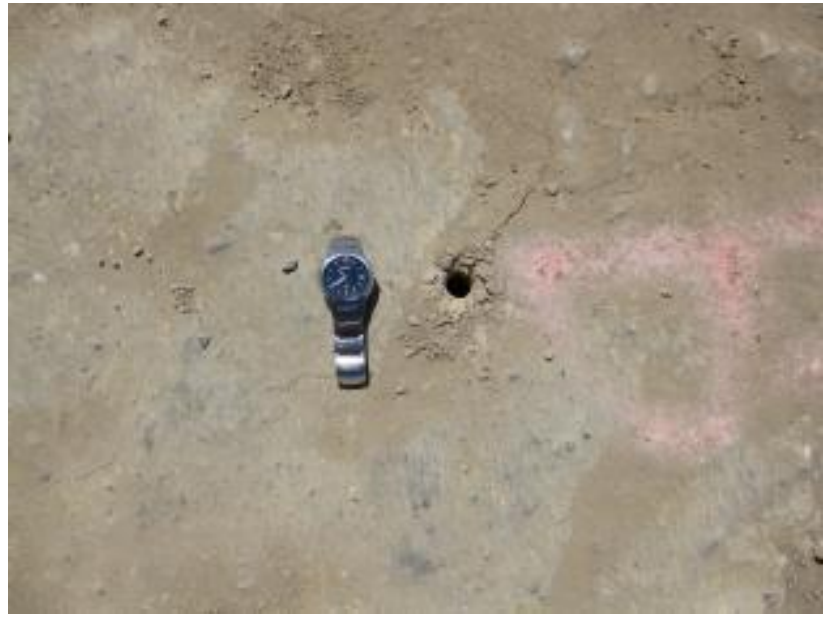

(b)

Figure 4 Effect of heavy trafficking of limestone waste rock by loaded haul trucks and watering: haul road (a); and close-up of hardpan surface (b)

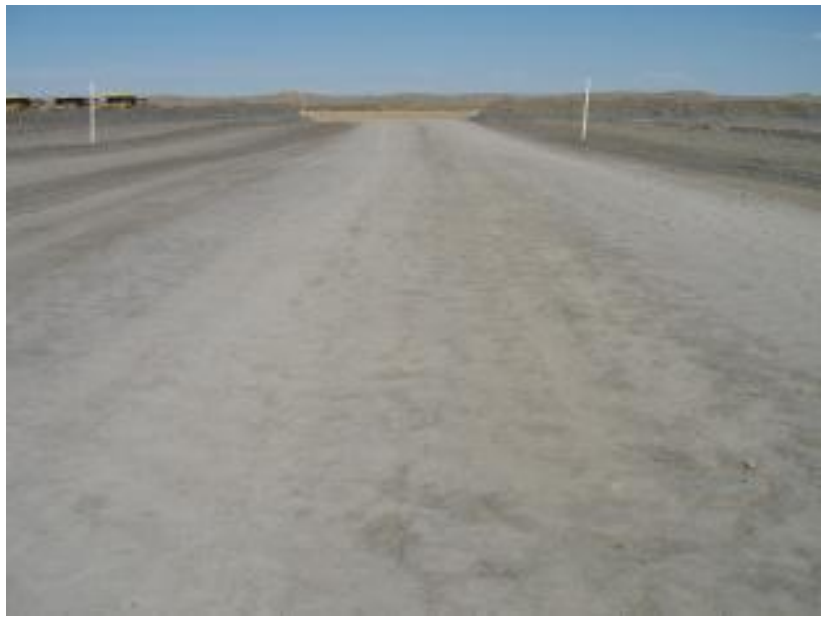

(a)

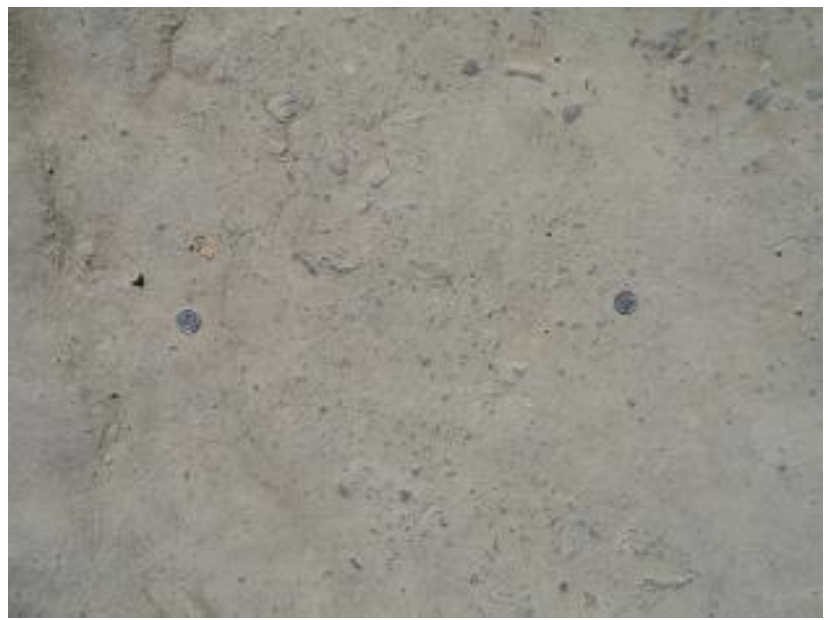

(b)

\section{Figure 5 Effect of heavy trafficking of shale waste rock by loaded haul trucks and} watering: haul road (a); and close-up of hardpan surface (b)

Following dozing, heavy compaction by loaded haul trucks and watering, limestone and shale waste rock on the top surface of the waste rock dump were subjected to field density and saturated hydraulic conductivity testing, and samples were taken for laboratory in situ gravimetric moisture content (= Mass of water/Mass of dry solids, expressed as a \%). Soil water characteristic curves (SWCCs) were estimated based on the particle size distributions, field dry density and specific gravities of the trafficked limestone and 
shale waste rock, using Fredlund et al. (1997) and the library of data contained within the SoilVision software (http://www.soilvision.com).

The field density was determined by a combination of water replacement and nuclear gauge testing, giving a range in dry density from 1.72 to $2.26 \mathrm{t} / \mathrm{m}^{3}$ and an average value of $2.02 \mathrm{t} / \mathrm{m}^{3}$, for a range in gravimetric moisture content from 1.4 to $7.8 \%$, with an average value of $2.7 \%$. Saturated hydraulic conductivities were measured using a CSIRO disc permeameter, showing that average values of $6 \times 10^{-8} \mathrm{~m} / \mathrm{s}$ and $6 \times 10^{-7} \mathrm{~m} / \mathrm{s}$ were achievable for dozed, heavily compacted and watered limestone and shale waste rock, respectively. The trafficked limestone and shale waste rock were found to be silty sandy gravel-sized, with about $80 \%$ gravel-sized by mass. The specific gravities of the limestone and shale waste rock determined by helium pycnometer averaged 2.84 and 2.75 , respectively.

Estimated SWCCS for the trafficked limestone and shale waste rock are shown in Figure 6, from which a matric suction of $1,000 \mathrm{kPa}$ was determined for the average in situ gravimetric moisture content of $2.7 \%$ (converted to an average volumetric water content = volume of water/total volume, of 0.07 ). The hydraulic conductivity functions for the trafficked limestone and shale waste rock estimated from the SWCCs using the method of Fredlund et al. (1994), and fixed in space by the saturated hydraulic conductivities achievable on dozing, heavy compaction by loaded haul trucks and watering, are shown in Figure 7. Also shown in Figure 7 is the estimated hydraulic conductivity of about $1 \times 10^{-15} \mathrm{~m} / \mathrm{s}$ (practically impermeable under this unsaturated condition) corresponding to the average in situ gravimetric moisture content and matric suction. The trafficked waste rock would need to be near-saturated to allow the passage of net percolation from the store-and-release cover, and this would only occur after a very heavy rainfall event or a series of intense rainfall events during an extreme wet season.

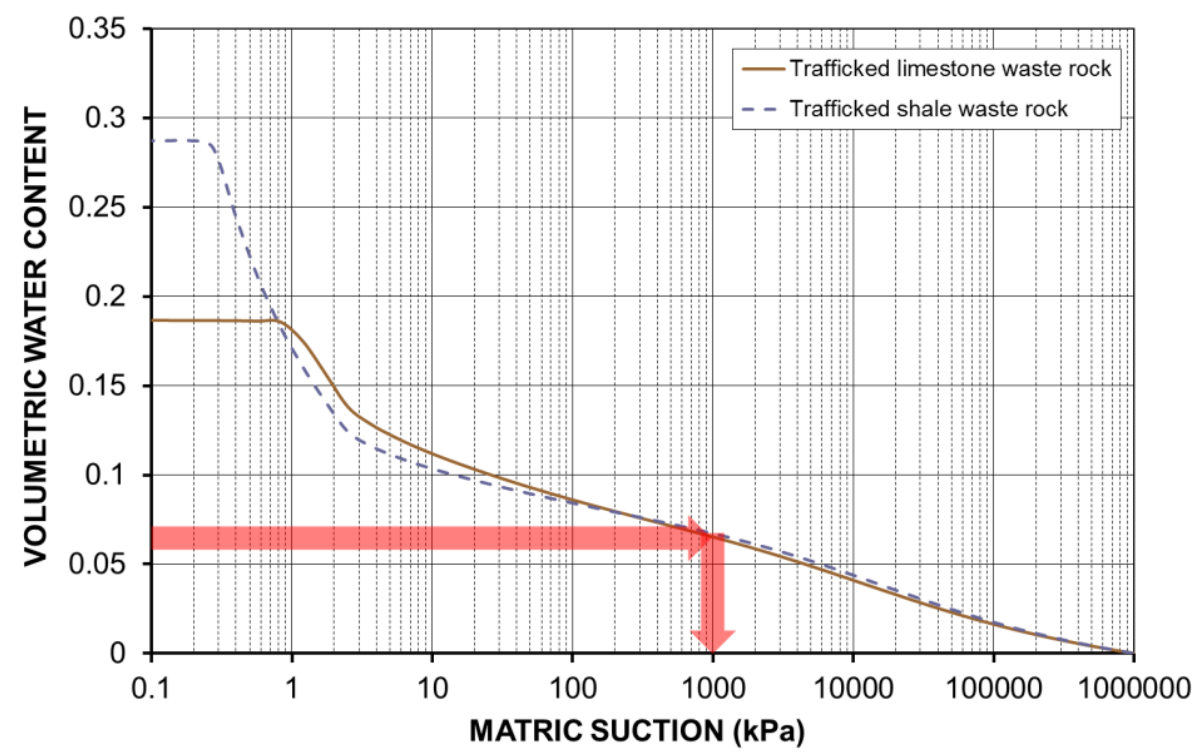

Figure 6 SWCCs for dozed, compacted and watered limestone and shale waste rock, showing estimated matric suction at average in situ volumetric water content

\subsubsection{Use of limestone waste rock}

Fresh, blocky or broken limestone waste rock (Figure 8) is suitable for use in the drainage layer at the base of the waste rock dump to drain any flowthrough beneath the dump and for the wide side encapsulation surrounding the reactive shale waste rock to limit its exposure to rainfall infiltration through the side slopes (Figure 9). Weathered limestone, preferably broken, although blocky may be acceptable, is suitable for use as the rocky soil mulch layer of the store-and-release cover, visually assessed based on Figure 10. 


\subsubsection{Use of topsoil}

A nominal $100 \mathrm{~mm}$ of the limited available silty topsoil was to be spread over the hummocky top of the store-and-release rocky soil mulch layer and ripped in, to augment the fines in the rocky soil mulch layer, aiding moisture retention and adding contained nutrients for vegetation.

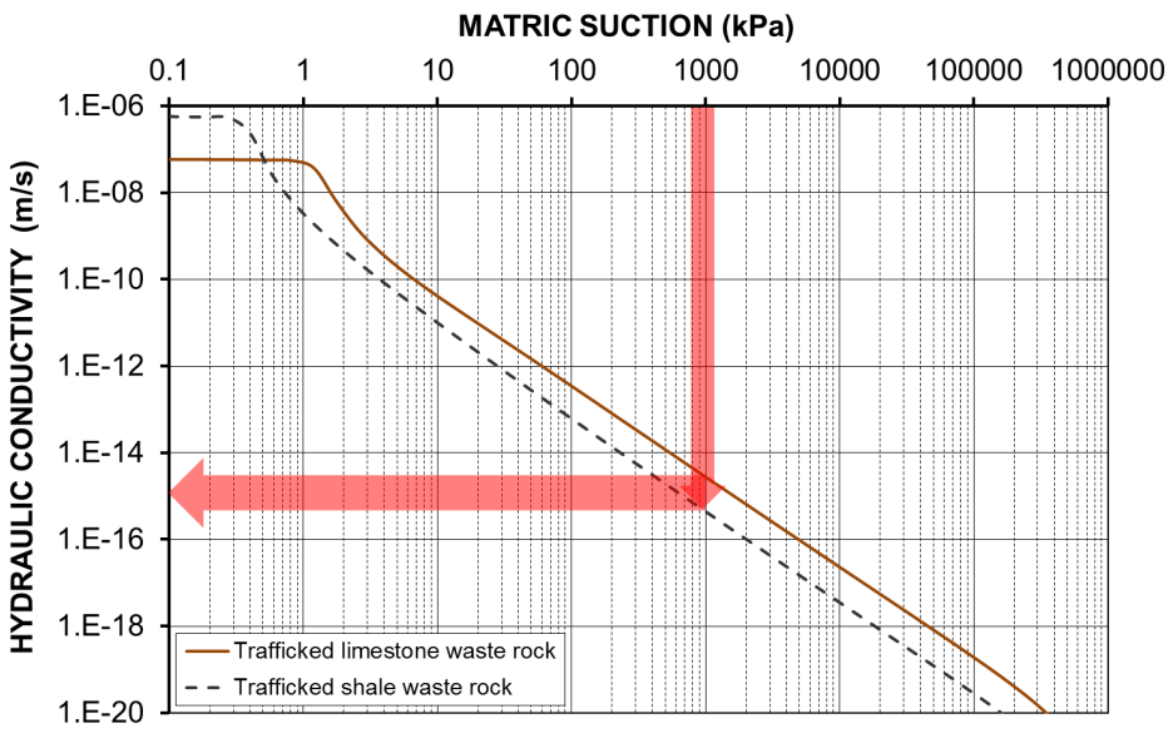

Figure 7 Hydraulic conductivity functions for dozed, compacted and watered limestone and shale waste rock, showing estimated hydraulic conductivity at average in situ volumetric water content

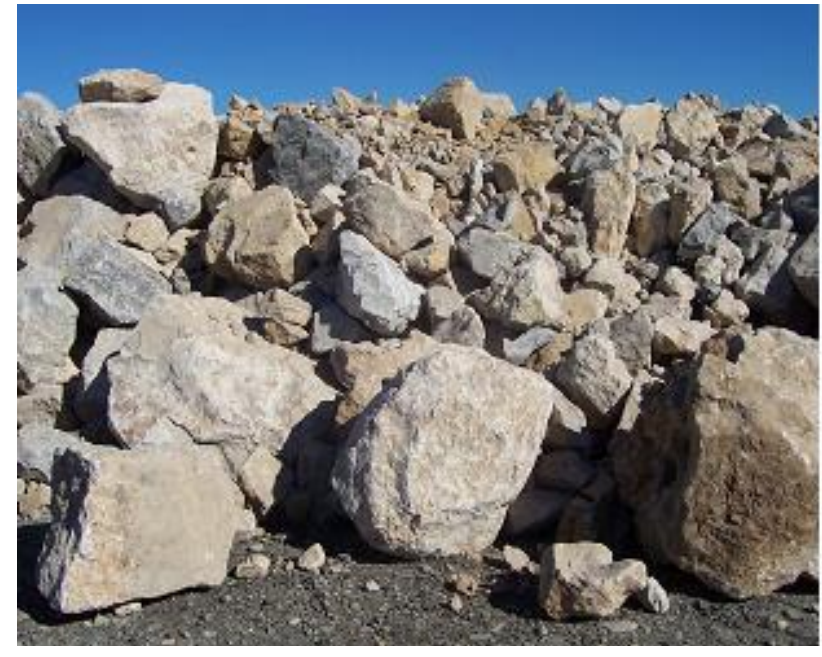

(a)

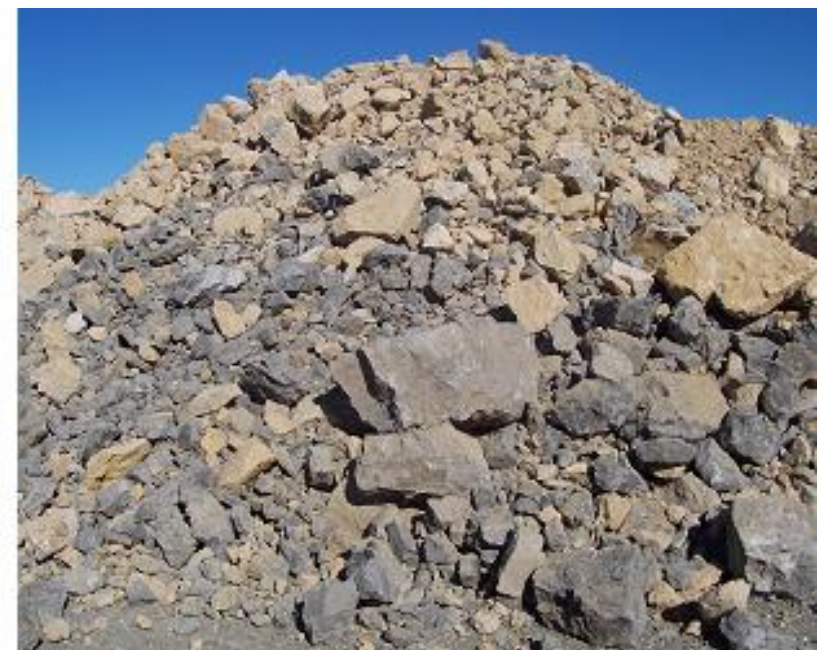

(b)

Figure 8 Fresh limestone waste rock suitable for basal drainage layer and side encapsulation of reactive shale waste rock: (a) blocky; (b) broken 


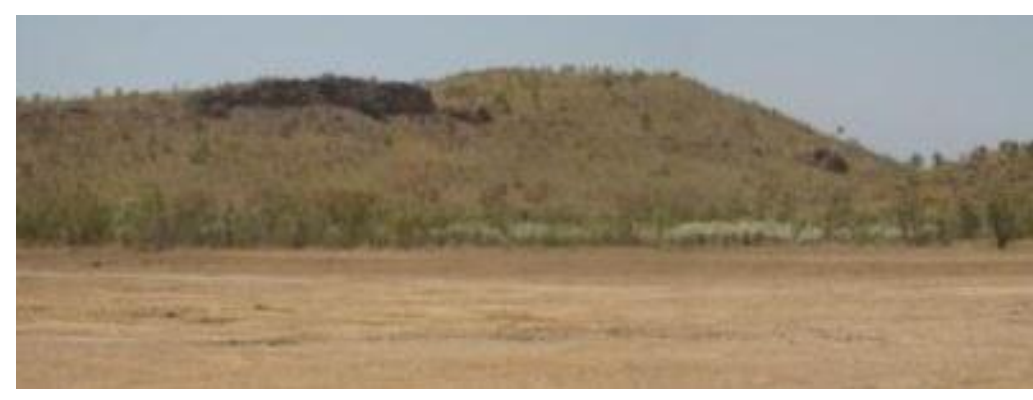

(a)

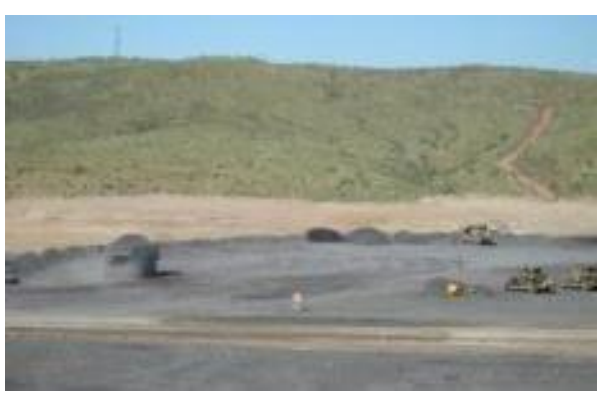

(b)

\section{Figure 9 (a) Fresh limestone waste rock used in basal drainage layer; and (b) wide side encapsulation of reactive shale waste rock}

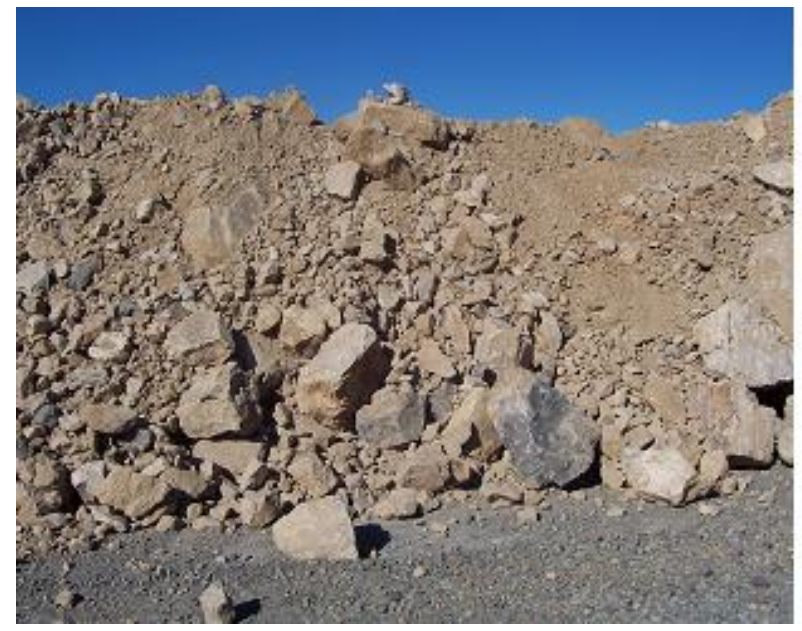

(a)

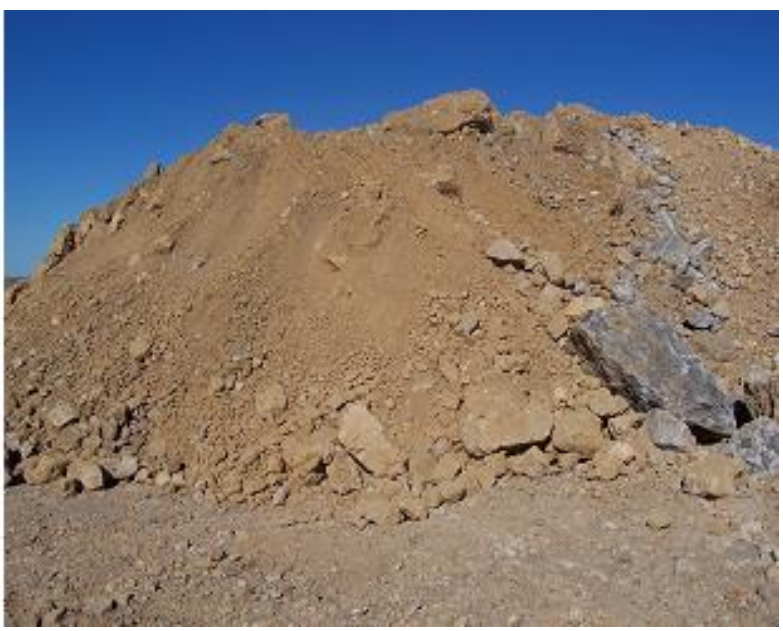

(b)

Figure 10 Weathered limestone waste rock suitable for use as rocky soil mulch in store and release cover: (a) blocky, acceptable; and (b) broken, preferred

\subsection{Detailed store-and-release cover design}

The detailed design of the store-and-release cover for use on the tops of waste rock dumps at Century mine is shown schematically in Figure 11. It consists of the following layers, starting from the base of the cover:

- Nominal $0.25 \mathrm{~m}$ thick reduced permeability sealing layer (RPL) formed by heavily compacting the dozed surface waste rock by loaded haul trucks and watering, which is underlain by the moderately traffic-compacted, horizontally bedded top layer of the waste rock dump.

- Minimum $1.5 \mathrm{~m}$ thick, loose, rocky soil mulch store and release layer, consisting of weathered limestone, with a hummocky surface to capture rainfall, smoothed by a low bearing pressure dozer to smear any preferred seepage paths and break down coarse particles.

- Nominal $100 \mathrm{~mm}$ of silty topsoil ripped into the weathered limestone rocky soil mulch layer to augment the fines in the rocky soil mulch layer, aiding moisture retention and adding contained nutrients for vegetation.

The loose-dumped, rocky soil mulch layer will have an initial porosity of about 0.3 , which will reduce over time to perhaps 0.2 . Hence, it will provide storage volume for rainfall infiltration of at least $300 \mathrm{~mm}$ - over half the median annual rainfall and almost half the average annual rainfall. It is anticipated that rainfall infiltration will account for about half of the total rainfall incident on the covered dumps during the wet season, the remainder going to rapid evaporation from the surface following rainfall events. Hence, there is sufficient storage capacity within the rocky soil mulch layer to handle average annual rainfall. Some rainfall will also re-wet the RPL. 


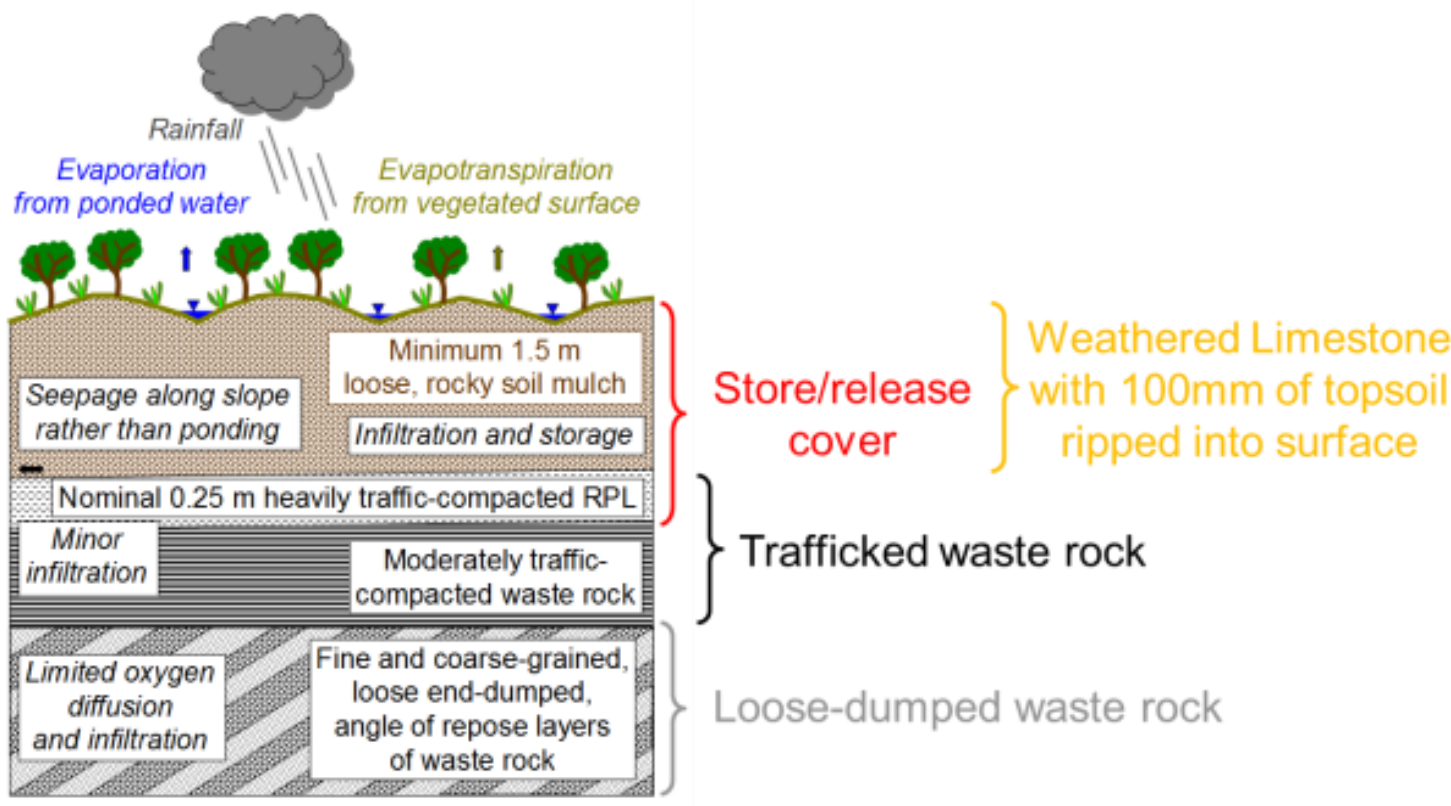

\section{Figure 11 Schematic of store-and-release cover for use on tops of waste rock dumps at Century mine}

The coarse-textured, hummocky surface of the store and release cover matches that found naturally surrounding Century mine (Figure 12).

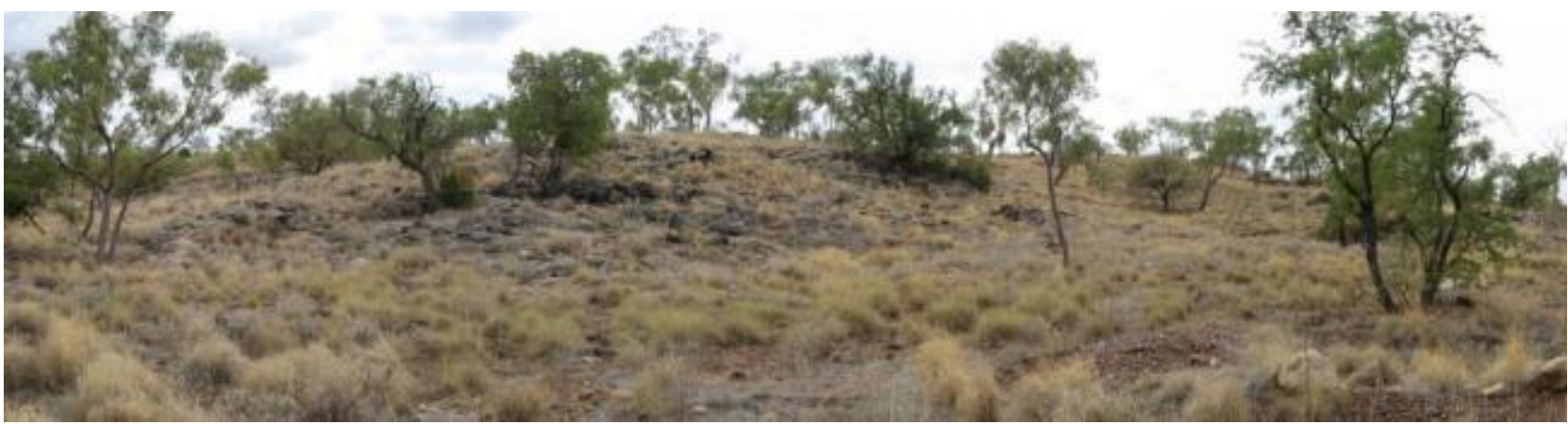

Figure 12 Natural, coarse-textured, hummocky surface surrounding Century mine

To accommodate above-average wet season rainfall totals, the compacted surface of the RPL is sloped towards the side of the dump, so that excess rainfall infiltration into the rocky soil mulch layer will flow across the compacted surface and spill over the sides of the dump, limiting the saturation of the RPL and reducing the potential for net percolation to the underlying reactive shale waste rock. Evidence that this works is seen in Figure 13, which was taken following an extreme rainfall event of about $300 \mathrm{~mm}$ over several days. Identified points at which spills emanate will be rock-lined to limit erosion.

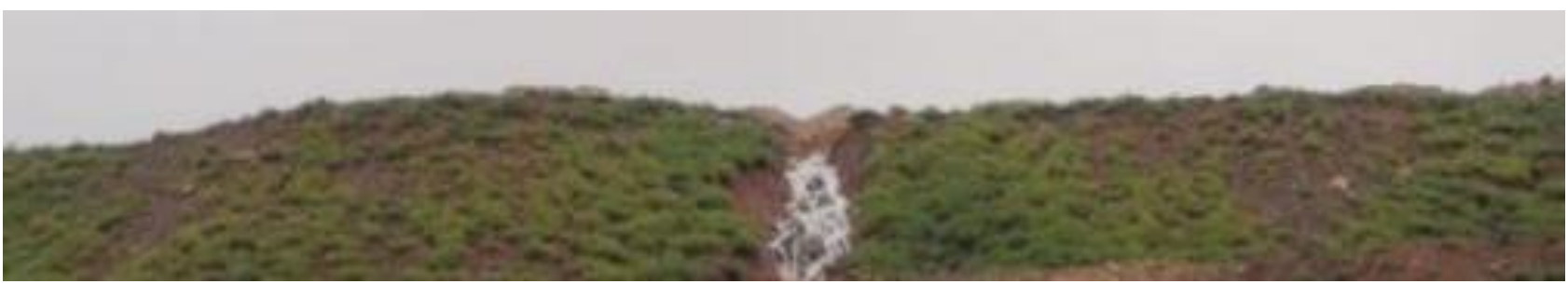

Figure 13 Spill of excess rainfall infiltration at base of store-and-release cover 


\section{$4 \quad$ Available soil cover performance data}

Numerous instrumented store-and-release covers have been constructed in dry climates at mine sites in Australia and the USA, and even more ET covers have been constructed on landfills in the USA.

\subsection{Performance of ACAP soil covers in dry climates}

The most comprehensive and reliable performance data from instrumented store-and release (ET) cover trials constructed in dry climates come from ACAP (USEPA, 2011), which are plotted, together with the performance data for membrane composite and compacted clay covers, in Figure 14. The membrane composite covers include a geomembrane or geosynthetic clay line over $0.45-0.6 \mathrm{~m}$ of compacted clay, overlain by one to three soil layers, depending on the hazard posed by the underlying wastes. The ET covers generally consist of a single, fine-grained layer 0.6-3 m thick, depending on the precipitation, with capillary breaks placed at the base in some cases to help maintain tension-saturation in the overlying finer-grained ET layer. The fine-grained layer forms a self-sealing layer at its base. Figure 14 demonstrates that ET covers generally limit net percolation to less than $1 \%$ of annual precipitation (the two outliers highlighted are for thin ET covers), and perform as well as membrane composite and compacted clay covers in dry climates.

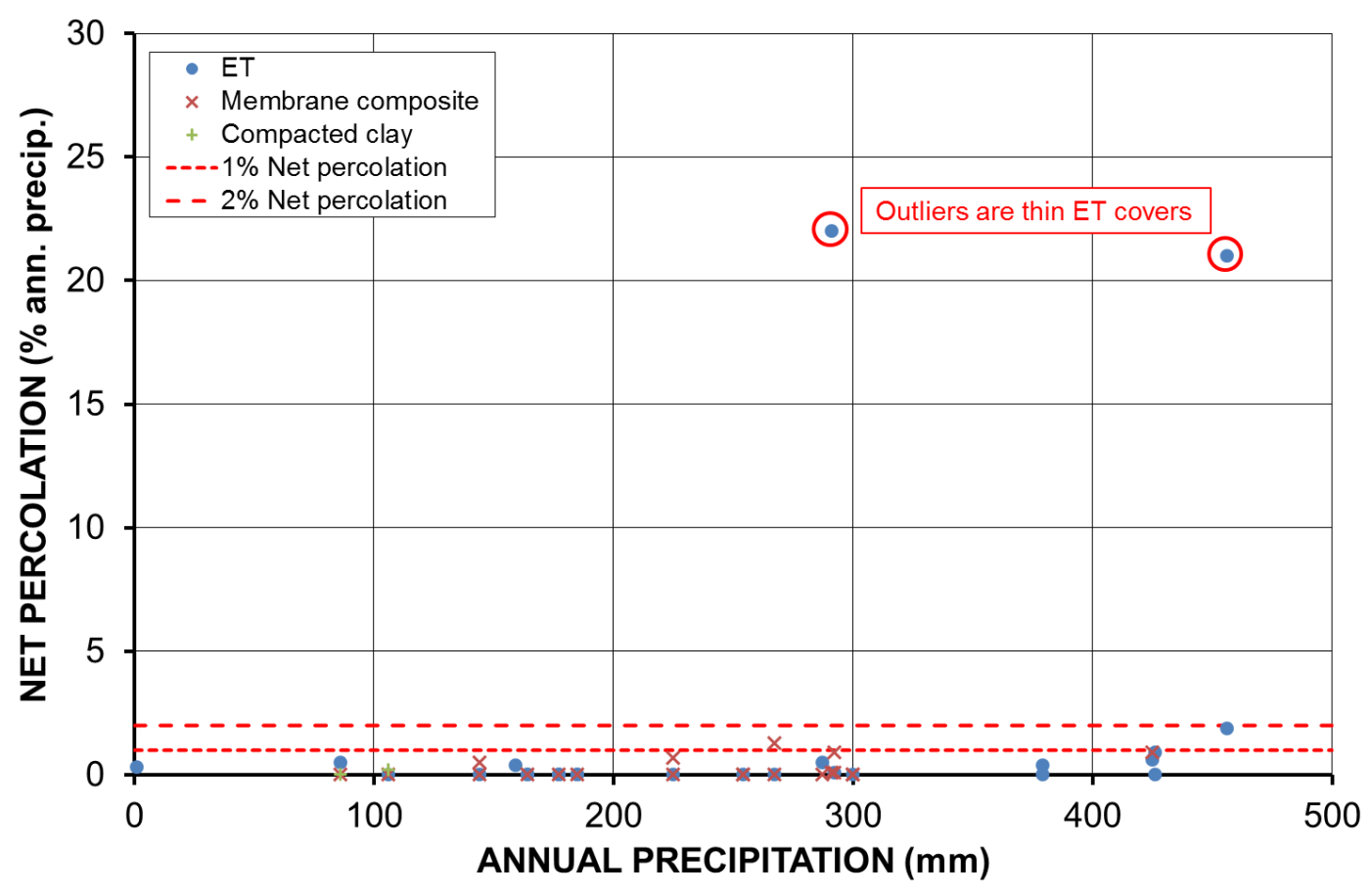

Figure 14 Comparison of net percolation for store-and-release (ET), membrane composite and compacted clay instrumented trial covers constructed in dry climates (after USEPA, 2011)

\subsection{Performance of store-and-release covers on waste rock dump tops in dry climates}

Store-and-release covers constructed in dry climates over waste rock dump tops, if properly designed and constructed, are effective in limiting net percolation to the underlying wastes for the duration of monitoring of up to about 10 years to date, and they have shown little sign of deterioration. The instrumented store-and-release covers constructed at Kidston have been shown to limit net percolation to less than $7 \mathrm{~mm} /$ year or less than $1 \%$ of average annual rainfall (Williams et al., 2006), while the instrumented store-and-release covers constructed at Goldstrike have been shown to limit net percolation to less than $5 \mathrm{~mm} /$ year or less than $2 \%$ of average annual precipitation (Zhan et al., 2006). 
Unfortunately, many of the intended store-and-release covers constructed at mines in Australia and elsewhere have not properly followed or implemented the essential elements of this soil cover system. In particular, many intended store-and-release covers have been deficient in not having a low hydraulic conductivity base layer to hold up rainfall infiltration in the cover and/or in applying run-of-mine waste rock as an overlying storage layer that is too coarse-grained to hold water and is devoid of nutrients to support vegetation and/or is constructed on slopes for which they are not suited. The result is relatively high net percolation, a poor vegetation cover and the inevitable deterioration of the soil cover over time. These failings have taken away from the excellent performance of the properly designed and constructed storeand-release covers.

The intended store-and-release covers described by Bonstrom et al. (2012) for the tops of waste rock dumps at a mine in the Pilbara region of Western Australia were deficient in not having a sealing layer and consisting of only sterile, coarse-grained run-of-mine waste rock, either $2 \mathrm{~m}$ (TP1) or $4 \mathrm{~m}$ thick (TP2). The resulting poor performance is summarised in Figure 15, which shows that net percolation through the cover occurred when the water stored in either cover exceeded about $60 \mathrm{~mm} / \mathrm{m}$ of cover thickness, or only $6 \%$, well below the $25 \%$ expected available storage. Above this storage threshold, a net percolation of up to $16 \%$ of annual rainfall was recorded. Further, net percolation through these covers occurred when annual rainfall exceeded about $370 \mathrm{~mm}$ or when cumulative rainfall from a number of years exceeded about $960 \mathrm{~mm}$.

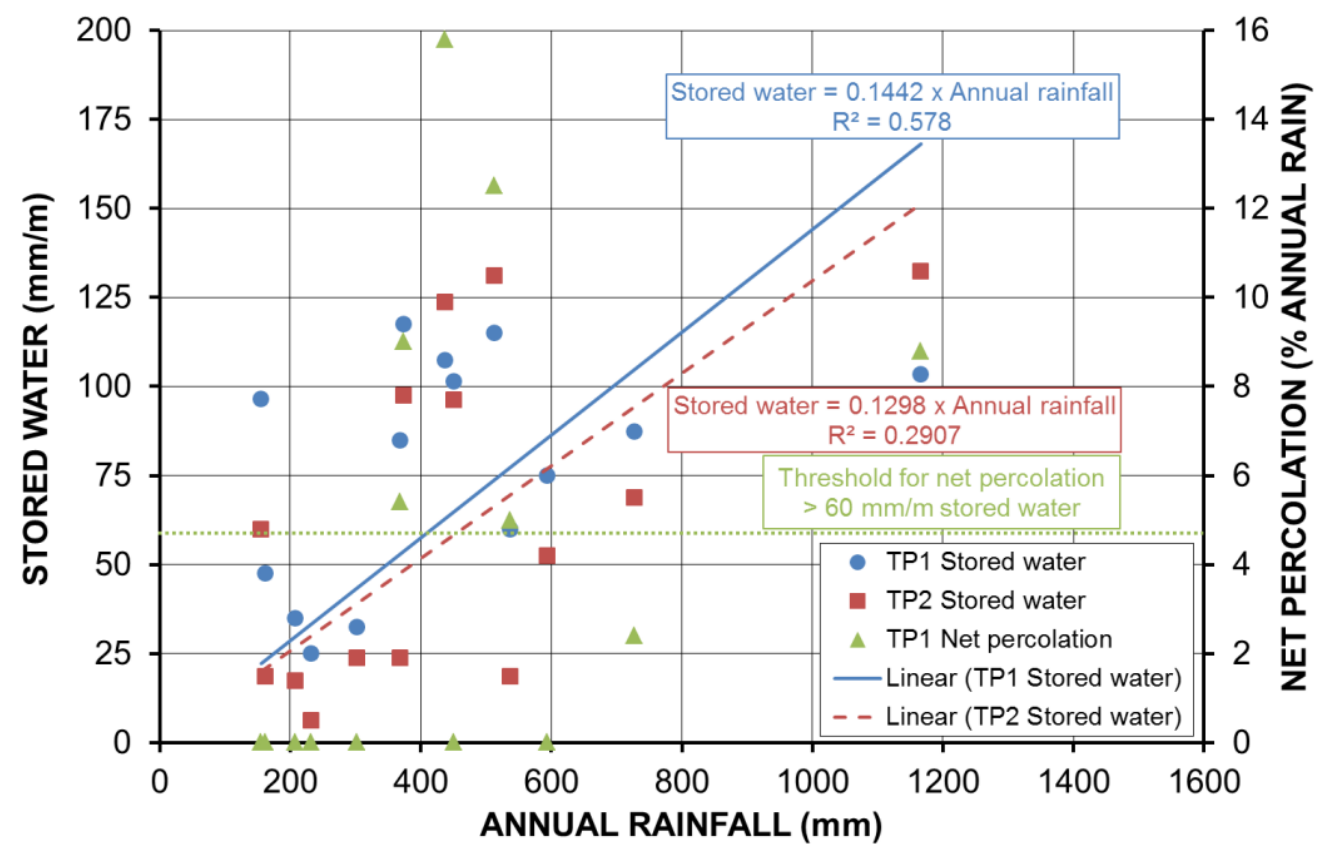

\section{Figure 15 Stored water and net percolation versus annual rainfall for intended store and release soil covers on waste rock dumps in the Pilbara region of Western Australia (sourced from Bonstrom et al., 2012)}

\section{Conclusions}

Worldwide literature and experience supports the use of store-and-release covers on waste rock dump tops in dry climates, and most of the available experience in the use of store-and-release or ET covers emanates from Australia and the drier parts of the USA.

The key elements of a store-and-release cover are a low hydraulic conductivity layer at its base, a hummocky surface on the thick overlying rocky soil mulch layer and the appropriate selection of vegetation species to cycle the water stored in the rocky soil mulch layer without a net wetting up or drying out annually. The available performance data for store-and-release or ET covers demonstrates that, if properly designed and constructed, they are effective in limiting net percolation to the underlying wastes to 
generally less than $1 \%$ of average annual rainfall for the duration of monitoring of up to about 10 years to date, and they have shown little sign of deterioration over this time period.

\section{Acknowledgement}

The author gratefully acknowledges the management of MMG Limited Century mine for allowing the publication of details from their site and for the assistance of their staff in facilitating the collection of the site data.

\section{References}

Ayres, B.K., O'Kane, M.O., Christensen, D. and Lanteigne, L. (2002) Construction and instrumentation of waste rock test covers at Whistle Mine, Ontario, Canada, in Proceedings Tailings and Mine Waste Vol. 02, 27-30 January, Fort Collins, Colorado, pp. 163-171.

Benson, C., Albright, W., Roesler, A. and Abichou, T. (2002) Evaluation of final cover performance: field data from the alternative cover assessment program (ACAP), in Proceedings Waste Management Vol. 02, 24-28 February 2002, Tucson, pp. 1-18.

Bonstrom, K., Allen, G., O'Kane, M. and Christensen, D. (2012) Evolution of cover system design and waste rock management at a mine in the Pilbara region of Western Australia, in Proceedings Mine Closure 2012, A.B. Fourie and M. Tibbett (eds), 25-27 September, Brisbane, Australia, Australian Centre for Geomechanics, Perth, pp. 351-364.

Diehl, P. (2001) Uranium Mining in Eastern Germany: The WISMUT Legacy, http://www.wise-uranium.org/uwis.html.

DITR (Department of Industry Tourism and Resources) (2006) Mine Rehabilitation Leading Practice Handbook, Australian Government.

DITR (Department of Industry Tourism and Resources) (2007) Managing Acid and Metalliferous Drainage Leading Practice Handbook, Australian Government.

DITR (Department of Industry Tourism and Resources) (2009) Mine Closure and Completion Leading Practice Handbook, Australian Government.

EGi (Environmental Geochemistry International) (1997) Waste Rock Characterisation for Century Mine.

Fredlund, M.D., Fredlund, D.G. and Wilson, G.W. (1997) Prediction of the soil water characteristic curve from grain size distribution and volume mass properties, in Proceedings Third Brazilian Symposium on Unsaturated Soils, 22-25 April, Rio de Janeiro, Brazil, $12 \mathrm{p}$.

Fredlund, D.G., Xing, A. and Huang, S. (1994) Predicting the permeability function for unsaturated soils using the soil water characteristic curve, Canadian Geotechnical Journal, Vol. 31, pp. 533-546.

GARD Guide (2009) Global Acid Rock Drainage Guide, http://www.gardguide.com.

INAP (International Network for Acid Prevention) (2003) Evaluation of the Long-term Performance of Dry Cover Systems, Final Report, O'Kane Consultants Inc. (ed.), Report No. 684-02.

MEND (Mine Environment Neutral Drainage Program) (2001) Prevention and Control, Vol. 4, Manual 5.4.2d., G.A. Tremblay and C.M. Hogan (eds), CANMET.

O'Kane, M.O. and Wels, C. (2003) Mine waste cover system design - linking predicted performance to groundwater and surface water impacts, in Proceedings Sixth International Conference on Acid Rock Drainage, 12-18 July, Cairns, Australia, pp. 341349.

Ricard, J.F., Aubertin, M., Firlotte, F.W., Knapp, R. and McMullen, J. (1997) Design and construction of a dry cover made of tailings for the closure of Les Terrains Aurifères site, Malartic, Québec, Canada, in Proceedings Fourth International Conference on Acid Rock Drainage, 31 May-6 June, Vancouver, Canada, Vol. 4, pp. 1515-1530.

Rykaart, E.M., Hockley, D., Noël, M. and Paul, M. (2006) Findings of international review of soil cover design and construction practices for mine waste closure, in Proceedings Seventh International Conference on Acid Rock Drainage, 26-30 March, St. Louis, Mo., pp. 1804-1822.

USEPA (2011) Fact Sheet on Evapotranspiration Cover Systems for Waste Containment, EPA 542-F-11-2011, http://www.epa.gov and http://www.cluin.org.

Wickland, B.E., Wilson, G.W., Wijewickreme, D. and Klein, B. (2006) Design and evaluation of mixtures of mine waste rock and tailings, Canadian Geotechnical Journal, Vol. 43, pp. 928-945.

Williams, D.J., Wilson, G.W. and Currey, N.A. (1997) A cover system for a potentially acid forming waste rock dump in a dry climate, in Proceedings Fourth International Conference on Tailings and Mine Waste, 13-17 January, Fort Collins, Colo., pp. 231235.

Williams, D.J., Currey, N.A. and Ritchie, P.J. (2003) Kidston waste rock dump design and 'store and release' cover system seven years on, in Proceedings Sixth International Conference on Acid Rock Drainage, 14-17 July, Cairns, Australia, pp. 419-426.

Williams, D.J., Stolberg, D.J. and Currey, N.A. (2006) Long-term performance of Kidston's 'store/release' cover system over potentially acid forming waste rock dumps, in Proceedings Seventh International Conference on Acid Rock Drainage, 26-30 March, St Louis, Mo., pp. 2385-2396.

Wilson, G.W., Williams, D.J. and Rykaart, E.M. (2003) The integrity of cover systems - an update, in Proceedings Sixth International Conference on Acid Rock Drainage, 14-17 July, Cairns, Australia, pp. 445-452.

Yanful, E.K. and Lin, M. (1998) An integrated approach to designing soil covers for reactive mine waste, in Proceedings Fifty-First Canadian Geotechnical Conference, 4-7 October, Edmonton, Canada, Vol. I, pp. 141-148. 
Zhan, G., Schafer, W., Milczarek, M., Myers, K., Giraudo, J. and Espell, R. (2006) The evolution of evapotranspiration cover system at Barrick Goldstrike Mines, in Proceedings Seventh International Conference on Acid Rock Drainage, 26-30 March, St Louis, Mo., pp. 2585-2603. 